\title{
MULHERES NEGRAS: A RELAÇÃO DE MOBILIDADE URBANO PERIFÉRICA COM A PERMANÊNCIA NA EDUCAÇÃO SUPERIOR
}

\author{
BLACK WOMEN: THE RELATION OF PERIPHERAL URBAN MOBILITY WITH THE \\ PERMANENCE IN HIGHER EDICATION
}

\author{
Renata Miranda Lima \\ Mestranda em Justiça, Empresa e Sustentabilidade \\ Universidade Nove de Julho, UNINOVE \\ renatamirandalima@yahoo.com.br
}

\section{RESUMO}

O presente estudo se volta às mulheres negras, universitárias, moradoras do distrito do M’boi Mirim - zona Sul / São Paulo com a finalidade de compreender o entrelaçamento do Direito a Mobilidade Urbano-Periférica com o Direito à Educação Superior. Para tanto, foi utilizada a observação qualitativa como estratégia metodológica, entrevistas semiestruturadas e uso de diário de campo. A partir do exposto conclui-se que: a mulher negra, moradora da periferia que está acessando o ensino superior, encontra no seu caminho de permanência na universidade, um bombardeio de dificuldades. Entretanto, essas mulheres reexistem, ressignificam e resistem por influência da família, por quererem atingir seus objetivos, sonhos e buscarem na educação uma mobilidade social para si e para sua família. Assim, resumo a força que as impulsionam na seguinte canção:

"Planta do pé tá no chão. Sangue dos meus ancestrais no coração. Alcançando a vitória com as próprias mãos. Alcançando a vitória com as próprias mãos. Com as próprias mãos. Se é pra vencer deixa quem sabe fazer. Eu tô na luta, sou mulher. Posso ser o que eu quiser". (Karol ConK: Tô na luta).

Palavras-chave: Mobilidade Urbana no Bairro. Mulheres Negras. Educação superior. Periferia. Jardim São Luís - São Paulo. 


\section{ABSTRACT:}

The present study is aimed at black women, university students, residents of the district of M'boi Mirim - South / São Paulo, in order to understand the interweaving of the Right to Urban-Peripheral Mobility with the Right to Higher Education. For that, qualitative observation was used as methodological strategy, semi-structured interviews and field diary use. From the above it is concluded that: the black woman, a resident of the periphery who is accessing higher education, finds a bombardment of difficulties on her way to university. However, these women reexist, resignify and resist by the influence of the family, wanting to achieve their goals, dreams and seek in education a social mobility for themselves and their families. So, I summarize the force that drives them in the following song:

"The bottom of the foot is on the floor.

Blood of my ancestors in the heart.

Reaching victory with his own hands. Reaching victory with his own hands. With his own hands.

If it's to win leaves who knows how to do. I'm in the fight, I'm a woman.

I can be whatever I want. “ (Karol ConK: I'm in the fight).

Keywords: Urban Mobility in the Neighborhood. Black Women. Higher Education. Periphery. Jardim São Luís - São Paulo.

Data de submissão: 23/03/2019

Data de aceitação: 03/07/2019

\section{SUMÁRIO}

INTRODUÇÃO 1. PROCEDIEMENTOS E METODOLOGIA 2. ACESSO AO BEM SOCIÁL EDUCAÇÃO É PARA QUEM? 3. ESCOLHEM OU SÃO ESCOLHIDAS 4. DESLOCAMENTO COMO UM DIREITO DE MEIO ESSENCIAL 5. CONTINUAR POR QUÊ? 6. QUESTOES DE RAÇA. CONSIDERAÇÓES FINAIS 


\section{INTRODUÇÃO}

A presente pesquisa é subsidiada e realizada por meio do projeto Jovens Pesquisadoras, criado pelo CDHEP - Centro de Direitos Humanos e Educação Popular - Campo Limpo, o qual está situado no bairro do Capão Redondo. O CDHEP é uma organização não governamental e tem como objetivo, promover estratégias de formação, articulação, comunicação e formulação de políticas públicas para prevenir e superar as diversas formas de violência existentes nas periferias.

O estudo acontece no distrito do M'Boi Mirim o qual tem área de $62,10 \mathrm{Km}$, população com 563.305 habitantes e densidade demográfica de $9.071^{1}$ é composto por 168 favelas em $2.357 .088 \mathrm{~m}^{2}$. Nestas há 48 áreas declaradas de risco ora por deslizamentos, transbordamento de córregos e enchentes ${ }^{2}$. A título de comparação populacional, o número de habitantes da regiâo é equivalente à populaçáo do país de Luxemburgo ${ }^{3}$.

Conforme dados da prefeitura do $\mathrm{M}^{\prime}$ Boi Mirim, 7,42\% das pessoas daquela regiáo a partir de 15 anos são analfabetas, $25 \%$ da população com 25 anos a mais, tem menos de 4 anos de estudo. Os dados também demonstram que a população mais jovem, entre 7 e 14 anos, tem alta frequência no ensino fundamental com índice de $91,10 \%$. Entretanto, quando a faixa etária muda para 15 a 17 anos, o índice cai para 44,57\%; ou seja, a metade destes não continuam os estudos e na grande maioria das vezes, o não continuar os estudos tem como pano de fundo uma questáo social ${ }^{4}$.

A partir do cenário tecido acima, questiona-se como é para as mulheres dessa regiáo a concretização do direito à educação superior por meio da mobilidade urbana? Mas o que seria mobilidade? Mobilidade é exemplo de Direito de Liberdade a qual, demanda prestaçôes positivas do Estado para sua concretização. Assim, a importância do Direito a Mobilidade Urbana, vista a partir do bairro e sob a perspectiva das mulheres negras tem a sua função ampliada, pois trata de um Direito de meio e Direito social, com uma especificidade decorrente da realidade do território e do gênero.

O estudo se volta mulheres negras porque essas enfrentam uma estrutura de discriminação diferenciada da mulher branca e essa discrepância se manifesta como resquícios históricos nos dias atuais. Isso não quer dizer que a mulher branca não sofre discriminação, por que está sofre, contudo, quando a discriminação recai sobre diferentes grupos sociais

\footnotetext{
1 São Paulo. Dados demográficos dos distritos pertencentes às Subprefeituras. 2010. Acessado em 20/03/2019. Disponível no site: < https://www.prefeitura.sp.gov.br/cidade/secretarias/subprefeituras/ subprefeituras/dados_demograficos/index.php? $\mathrm{p}=12758>$.

2 SÃO PAULO. Secretaria de coordenaçáo das subprefeituras. Diagnóstico de $\mathbf{M}^{\prime}$ boi Mirim, 2008, p. 1 a 3. Disponível no site< http://ww2.prefeitura.sp.gov.br/arquivos/subprefeituras/spmb/dados/ diagnosticos_de_mboi_mirim-08_08_08.pdf >. Acesso em: 23 de jul. 2017.

Conforme informação disponível no site "Le Portail Des StatisquesGran-Duché De Luxembourg". Disponível no site: <http://www.statistiques.public.lu/fr/population-emploi/rp2011/caracteristiques-personnelles/index.html> Acesso em: 25 de jul. 2017.

SÃO PAULO. Secretaria de coordenação das subprefeituras. Diagnóstico de M’boi Mirim, 2008, p. 1 e 2. Disponível no site< http://ww2.prefeitura.sp.gov.br/arquivos/subprefeituras/spmb/dados/ diagnosticos_de_mboi_mirim-08_08_08.pdf >. Acesso em: 23 de jul. 2017.
} 
marginalizados, esta também vai pressupor tratamentos diferenciados e específicos daquele grupo social. Segundo o professor Adilson Moreira:

(...) mulheres são constantemente discriminadas no mercado de trabalho, mas mulheres brancas e negras não são tratadas da mesma forma. Mulheres brancas sofrem as consequências do sexismo, mas a experiência social delas e consecutivamente diferente da vivência social das mulheres negras, porque além do sexismo também enfrentam o racismo 5 .

Daí nasce a necessidade de um estudo com recorte de raça e gênero. Para tanto é utilizado o método bola de neve o qual tem como finalidade, a produção de um estudo qualitativo em amostragem probalística ${ }^{6}$ a qual se iniciou com cinco entrevistas, que ocorreram individualmente ficando, ao final, com o total de sete entrevistas. É importante ressaltar que foram dados nomes fictícios às colaboradoras com a finalidade de resguardar sigilo, protegendo sua imagem. Foi utilizado, gravador para auxiliar na transcriçáo das falas, termo de livre consentimento esclarecido - TCLE, formulário de caracterização já anexado abaixo na figura 1 e as perguntas semiestruturadas incluídas no início do próximo tópico na forma de objetivos ${ }^{7}$.

Com base nas entrevistas realizadas, pode-se concluir que: as dificulta de permanência dessas mulheres no ensino superior decorrem do medo constante de furto, roubo e violência sexual; sentimentos de insegurança; dificuldades financeiras e barreiras histórias. Também há a questâo do excesso de afazeres que recai principalmente sobre as mulheres que são trabalhadoras, mães que cuidam, levam e trazem os filhos da creche e escola, esposas, filhas e donas de casa que cuidam das suas coisas e são responsáveis pelos seus familiares. Esses afazeres corroem o já escasso tempo que primeiro foi corroído pelo trânsito de São Paulo para ir e voltar da faculdade, para ir e voltar do serviço, para ir e voltar do médico, da farmácia, do mercado, da feira, da escola do filho. Todo esse vai e vem, diminui o tempo e dificulta que essas mulheres estudem como querem e precisam, e isso interfere na permanência delas no ensino superior com qualidade.

\section{PROCEDIMENTOS E METODOLOGIA}

A presente pesquisa teve como objetivo norteador compreender como a mobilidade permite ou possibilita o acesso e permanência de mulheres negras na educaçáo superior. No

\footnotetext{
5 MOREIRA, A. J. O que é discriminaçáo? 2017, p. 33.

6 VITUNO. J. A Amostragem em Bola de Neve na Pesquisa Qualitativa: Um Debate em Aberto. Revista dos pós-graduandos em ciências sociais. IFCH Unicamp. Temáticas, Campinas, 22, (44): 203, ago./dez. 2014. Disponível no site: <https:/www.ifch.unicamp.br/ojs/index.php/tematicas/article/ view/2144/1637>. Acesso em: 07 de jul. 2017.
}

7 GIL, A. C. Métodos e Técnicas de Pesquisa Social, 1989, p. 206. 
entanto, houve objetivos específicos, que funcionaram como marcos para a pesquisa, viabilizando uma compreensão mais aprofundada a partir dos seguintes pontos:

\section{Razóes de escolha da universidade;}

1.1 Por que a escolha do período noturno;

2. Deslocamento na ida e volta à Universidade dessas mulheres.

2.1 Meios de transportes que usam no percurso entre universidade e casa;

2.2 Como é para essas mulheres usar os meios de transportes informados;

2.3 Deslocamento do terminal de ônibus à moradia;

3. Dificuldades enfrentadas para chegar a universidade e voltar à casa.

3.1 O que promove a permanência delas na universidade;

3.2 Dificuldades no dia a dia da universidade;

4. Como é a questão do Racismo para elas.

A partir dos objetivos traçados foi feita uma pesquisa bibliográfica inicial à construção da base teórica sobre o tema. Também é utilizado a legislação relacionada a organização da cidade como o plano diretor estratégico, a Constituição Federal. Após essa fase foi elaborado um questionário (figura 1) para viabilizar uma breve caracterização das participantes (figura 2). Assim, iniciou-se a fase de procura das pessoas que colaborariam com a pesquisa por meio de entrevistas. Dentre as várias formas ou caminhos para se chegar a essas pessoas, optou-se pelo método Bola de Neve, o qual tem como finalidade, a produção de um estudo qualitativo em amostragem. A metodologia Bola de Neve é um instrumento eficaz em estudos focados em grupos de difícil localização, por tais razóes esse procedimento é utilizado no presente estudo, sendo certo que está não é uma amostra probalística ${ }^{8}$.

Para a execução da amostragem, o estudo se inicia por meio de informantes chaves que são chamadas de sementes, as quais serão entrevistadas e também auxiliarão na localização de outras indicando mulheres negras, universitárias e moradoras do Distrito do M’Boi Mirim ${ }^{9}$. No convite das primeiras sementes, foram utilizadas como critério as seguintes características: mulheres negras, do círculo social da pesquisadora, que estudam no período noturno em Universidades diversas e que residam no distrito do M’boi Mirim. Para que a pesquisa tenha maior diversidade, não foi colocado limite de idade o que resultou em participantes com características diferentes em relação à faixa etária, curso, estado civil etc. Trata-se, portanto, de uma amostra intencional, a qual se iniciou com cinco entrevistas, que ocorreram individualmente ficando, ao final, com o total de sete entrevistas. Cada entrevista foi feita, procurando sempre um local capaz de ser mais acolhedor e mais fácil para as entrevistadas no sentido de evitar locomoção, levando em consideração que todas são univertárias, trabalham, algumas são casadas e tem filhos.

$8 \quad$ VITUNO. J. A Amostragem em Bola de Neve na Pesquisa Qualitativa: Um Debate em Aberto. Revista dos pós-graduandos em ciências sociais. IFCH Unicamp. Temáticas, Campinas, 22, (44): 203, ago/ dez. 2014. Disponível em: <https://www.ifch.unicamp.br/ojs/index.php/tematicas/article/view/2144/1637>. Acesso em: 07 jul. 2017.

9 Idem, 2014, p. 205. 
É importante ressaltar que essa fase de entrevista foi um ato de coprodução entre entrevistadas/colaboradoras e pesquisadora, pois nestes momentos ambas refletiram sobre como é essa questão da mobilidade no bairro, houve negociação de sentidos entre a pesquisadora e a entrevistada, troca de experiências, compreensão das realidades, demonstração de sentimentos com risadas e choros tudo isso durante sua coproduçáa ${ }^{10}$. Foi utilizado, gravador para auxiliar na transcrição das falas, o termo de livre consentimento esclarecido - TCLE (anexo 1 p. 24) e nove perguntas que foram organizadas a partir do roteiro (anexo 2 p. 24).

É importante ressaltar que foram dados nomes fictícios às colaboradoras com a finalidade de resguardar sigilo, protegendo sua imagem. Por outro lado, em decorrência da aproximação com as colaboradoras, será contada um pouco da história dessas mulheres como forma de aproximar o leitor da realidade delas, entretanto, de forma pontual e dentro do que interessava à pesquisa. Ressalta-se que tal relação é algo inevitável, pois "quando conversamos, dialogamos, contamos algo, nossas palavras referem-se ao mundo que nos envolve com sua realidade e suas ficçôes" ${ }^{11}$.

E por fim, como o foco do estudo são as questôes da mulher negra na periferia, a pesquisa terá como contexto o cotidiano da periferia. Conforme Peter Spink, cotidiano não é uma parte corriqueira e irrelevante da vida, separada e distinta dos acontecimentos importantes muito menos é algo meramente mundano. Na realidade, cotidiano é tudo que temos, portanto, todos nós vivemos o cotidiano, independentemente de sermos presidentes, prefeitos, reis, rainhas, chefes, escriturários ou pessoas em situação de rua. Assim, "todos nós, independentemente de onde estamos e quem somos, acordamos pela manhã e entramos no dia que temos pela frente; dia este que nada mais é que um fluxo de fragmentos corriqueiros e de acontecimentos em micro-lugares," que são importantes acasos diários ${ }^{12}$.

\footnotetext{
10 SPINK; BRIGAGÃO; NASCIMENTO; CORDEIRO. A produção de informaçáo na pesquisa social: compartilhando ferramentas, 2014. p 58.

11 MENDES, C. E. Os sentidos de futuro para jovens: por caminhos do capão redondo e do jardim ângela na periferia paulista, 2017. p. 14. Disponível em: <file://C:/Users/Renata\%20Miranda/Downloads/ mendes_corrigida-1.pdf>. Acesso em: 23 de jun de 2017.

SPINK, P. K. O pesquisador conversador no cotidiano. Revista de Psicologia Social. v.20. Porto Alegre, 2008, p 2. Disponível no site <http://www.scielo.br/scielo.php?script=sci_arttext\&pi$\mathrm{d}=$ S0102-71822008000400010 >. Acessado em 23/06/2017.
} 
Figura 1- Formulário de caracterizaçáo pessoal 2017 - Sáo Paulo/SP

\begin{tabular}{|l|l|}
\hline \multicolumn{2}{|l|}{ CDHEPY Formulário de caracterizą̧äo pessoal 2017-Säo Paulo/SP } \\
\hline Nome: & \\
\hline Sexo & \\
\hline Cor & \\
\hline Idade & \\
\hline Bairro residencial & \\
\hline Estado civil & \\
\hline Quantidade de filhos & \\
\hline Dados de caracterizạăoo universitária \\
\hline Universidade & \\
\hline Campus & \\
\hline Quando iniciou & \\
\hline Horário de aula & \\
\hline
\end{tabular}

Fonte: Confeccionado pela autora. Sáo Paulo 2017.

Figura 2 - Quadro de caracterizaçáo das participantes 2017 - Sáo Paulo/SP

\begin{tabular}{|c|c|c|c|c|c|c|c|c|c|}
\hline \multicolumn{10}{|c|}{ Quadro de caracterizaçío das participantes 2017 - Sáo Paulo/SP } \\
\hline $\begin{array}{l}\text { Nomes } \\
\text { Ficticios }\end{array}$ & $\begin{array}{l}\text { Sex } \\
0\end{array}$ & Cor & $\begin{array}{l}\text { Idad } \\
\text { e }\end{array}$ & Bairro residencial & $\begin{array}{l}\text { Estado } \\
\text { civil }\end{array}$ & Filhos & $\begin{array}{l}\text { Universidade } \mathrm{e} \\
\text { campus }\end{array}$ & $\begin{array}{l}\text { Quando } \\
\text { iniciou }\end{array}$ & $\begin{array}{l}\text { Horário } \\
\text { de aula }\end{array}$ \\
\hline $\begin{array}{l}\text { Tainá } \\
{ }^{13} \text { Dacia }\end{array}$ & $\mathrm{F}$ & Negra & 19 & Jardim casa Blanca & Solteira & 0 & Puc-SP Perdizes & 2017 & Noturno \\
\hline $\begin{array}{l}\text { Maria } \\
{ }^{14} \text { Anaya }\end{array}$ & F & Negra & 42 & Capão Redondo & Casada & 2 & $\begin{array}{l}\text { Sumaré-Santo } \\
\text { Amaro }\end{array}$ & 2014 & Noturno \\
\hline${ }^{15} \mathrm{Badu}$ & F & Parda & 21 & $\begin{array}{l}\text { Parque Santo } \\
\text { Antônio }\end{array}$ & Solteira & 0 & $\begin{array}{l}\text { Uninove-Santo } \\
\text { Amaro }\end{array}$ & 2017 & Noturno \\
\hline $\begin{array}{l}\text { Isabela } \\
{ }^{16} \text { Chioma }\end{array}$ & $\mathrm{F}$ & Negra & 22 & Jardim Mitsutani & Solteira & 0 & $\begin{array}{l}\text { Anhanguera- } \\
\text { Campo Limpo }\end{array}$ & 2016 & Noturno \\
\hline $\begin{array}{l}\text { Sarah } \\
{ }^{17} \text { Elon }\end{array}$ & $\mathrm{F}$ & Parda & 28 & $\begin{array}{l}\text { Jardim Såo Bento } \\
\text { Novo }\end{array}$ & Solteira & 0 & $\begin{array}{l}\text { Sumaré Santo } \\
\text { Amaro }\end{array}$ & 2014 & Noturno \\
\hline $\begin{array}{l}\text { Malu } \\
{ }^{18} \text { Amina }\end{array}$ & F & Negra & 29 & Alto do Rivicira & Casada & 1 & $\begin{array}{l}\text { Unisa-Santo } \\
\text { Amaro }\end{array}$ & 2016 & Noturno \\
\hline $\begin{array}{l}\text { Haydee } \\
\text { 19Dandara }\end{array}$ & $\mathrm{F}$ & Negra & 36 & Campo Limpo & Casada & 2 & $\begin{array}{l}\text { Anhanguera- } \\
\text { Campo Limpo }\end{array}$ & 2014 & Noturno \\
\hline
\end{tabular}

Fonte: Confeccionado pela autora. Sáo Paulo 2017. 


\section{FIGURA 3}

\begin{tabular}{|c|c|c|c|}
\hline \multicolumn{4}{|c|}{ Quadro de resultados 2017 - Sáo Paulo/SP } \\
\hline $\begin{array}{l}\text { Razóes de escolha da } \\
\text { universidade }\end{array}$ & $\begin{array}{l}\text { Deslocamento e Dificuldades } \\
\text { enfrentadas para ir e vir das } \\
\text { Universidades }\end{array}$ & Mcios de resistência & Racismo \\
\hline $\begin{array}{l}\text { Acesso a bens sociais năo é } \\
\text { para todos ou para algund }\end{array}$ & Distância........................... & Familia................... 4 & $\begin{array}{l}\text { O racismo existe } \\
\text { sim....7 }\end{array}$ \\
\hline $\begin{array}{l}\text { Não escolhem, sáo } \\
\text { escolhidas!....................... }\end{array}$ & Segurança: ......................... & Bolsa..................... 1 & $\begin{array}{l}\text { Branqueamento... } \\
\ldots \ldots+\ldots . .5\end{array}$ \\
\hline Qualidade: & Lotado .............................. & Trabalho/Financeira....2 & $\begin{array}{l}\text { A dor do } \\
\text { racismo.......7 }\end{array}$ \\
\hline Mobilidade social: & Tempo de cspera do ônibus & $\begin{array}{l}\text { Auxilios em xerox, alimentaçáo, } \\
\text { transporte................ } 3\end{array}$ & $\begin{array}{l}\text { Poder de } \\
\text { escolha.........5 }\end{array}$ \\
\hline $\begin{array}{l}\text { Libertar de preconceitos } \\
\ldots \ldots+. . . .2\end{array}$ & Trànsito lento ................... 3 & $\begin{array}{l}\text { Amor a profissáo / ajudar as } \\
\text { pessoas......... } 3\end{array}$ & \\
\hline $\begin{array}{l}\text { Educaçio como } \\
\text { transformaçio...............3 }\end{array}$ & & Aringir o objerivo e sonhos............ 3 & \\
\hline Financeiro................................ & & & \\
\hline
\end{tabular}

Fonte: Confeccionado pela autora. São Paulo 2017.

\section{ACESSO AO BEM SOCIAL EDUCAÇÃO É PARA QUEM?}

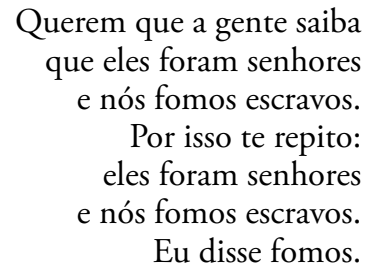

Oliveira Silveira (1941-2009) - O Poeta da Consciência Negra

A luz do poema a cima, apesar de poder dizer que "fomos escravos", as realidades tecidas nas entrevistas mostraram que algumas coisas se reinventam e se recriam no tempo perpetuando algumas situaçóes. Essa discussão é necessária porque, no geral a fala das que colaboraram com o desenvolvimento deste trabalho deixou em evidência que acessar bens sociais não é para todos:

"A educação transforma as pessoas e eu percebi que esse poder de transformar é tấo grande e por causa disso ela é pouco acessível. Porque se ela transforma e se todas as pessoas tivessem acesso à educação, teríamos pessoas transformadas e talvez esse náo seja o objetivo do poder dominante né?" (Depoimento de Tainá Dacia)

A partir da fala da Tainá, se extrai a categoria, acesso a bens sociais para alguns, e se é para 
alguns, se pressupóe uma desigualdade de acesso. Entretanto, para falar de desigualdade de acesso de Direitos Sociais referentes à população negra, em especial a educação, é preciso considerar que a construção da imagem do negro se formou pela objetificação do humano negro. Portanto, não tinha como o objeto acessar Direitos e daí nasce as diferenças materiais e sociais. Na questão da educação, a população negra ficou durante anos inviabilizada de ter acesso, pois o regulamento 22 de agosto de 1887 da província do Estado de São Paulo ${ }^{13}$ dizia no seu artigo $143 \$ 5^{\circ}$ que "não serão admittidos a matricula nas escolas de primeira cathegoria: Os escravos, salvo nos cursos nocturnos e com consentimento dos senhores". Como consequência, a populaçáo negra em sua grande maioria era analfabeta. Importante salientar que o Decreto n 21.076 de 1932 no seu artigo $4^{\circ}$ "b" dizia que "Não podem alistar-se eleitores analfabetos" ${ }^{14}$.

Mulheres não tinham direito a voto, mas, a partir do Código Eleitoral de 1932 o artigo $2^{\circ}$ que dizia: "E' eleitor o cidadão maior de 21 anos, sem distinção de sexo, alistado na forma deste Código", elas passaram a votar, contudo, somente as que sabiam ler e assim não só a mulher negra, mas toda populaçáo negra foi afastada de Direito de participaçáo e cidadania.

Outra questão histórica importante a ser ressaltada é que, embora o ensino superior estivesse presente no Brasil desde 1808, mulheres acessassem o ensino superior após 71 anos em 1879 por meio do Decreto $\mathrm{n}^{\circ} 7.247$, de 19 de abril ${ }^{15}$ que permitiu a elas ingressarem na educação superior. Mas questiona-se, quais estavam em condiçóes de ingressar no ensino superior? As mulheres não negras, pois a população negra no geral só acessou educação básica muito depois.

Dados do IBGE de 2010 corroboram o exposto acima, informando que o número de pessoas brancas entre 18 e 24 anos de idade que estavam frequentando o ensino superior era de 186.952, enquanto o número de pessoas pretas e pardas era de $50.069^{16}$. Ou seja, a populaçáo branca, na capital de São Paulo, é quase quatro vezes superior ao número de pessoas pretas e pardas no ensino superior. De acordo com dados do IPEA, que abrangem o período de 1995 a 2009, a taxa de mulheres no ensino superior cresceu muito neste período e se manteve superior a dos homens. Contudo, tais dados sugerem que há uma realidade escondida, pois ao levar em consideração raça, o que se percebeu foi uma dis-

13 SÃO PAULO. Regulamento de 22 de agosto de 1887 da província do Estado de São Paulo. Regulamento para instrucçáa publica Provincial 1887. Disponível no site: < http://www.usp.br/niephe/bancos/ legis_detalhe.asp?blg_id=205>. Acesso em: 23 out. 2017.

14 BRASIL. Decreto n 21.076 de 24 de fevereiro 1932. Código Eleitoral. Disponível em: <http:// www2.camara.leg.br/legin/fed/decret/1930-1939/decreto-21076-24-fevereiro-1932-507583-publicacaooriginal-1-pe.html>. Acessado em 23/10/2017.

15 BRASIL, Decreto $\mathrm{n}^{\circ}$ 7.247, de 19 de abril de 1879. Reforma o ensino primario e secundario no municipio da Côrte e o superior em todo o Império. Disponível em: <http://www2.camara.leg.br/le$\mathrm{gin} / \mathrm{fed} /$ decret/1824-1899/decreto-7247-19-abril-1879-547933-publicacaooriginal-62862-pe.html>. Acesso em: 08 jun. 2017.

16 SÃO PAULO. Instituto Brasileiro de Geografia e Estatística, censo demográfico. Sistema nacional de informação de gênero. Total de pessoas pretas ou pardas entre 18 e 24 anos de idade que frequentam o ensino superior. Disponível no site <http://cidades.ibge.gov.br/cartograma/mapa.php?lang=\&coduf=35\&codmun $=350950 \&$ idtema $=132 \& \operatorname{codv}=v 43 \&$ search $=$ sao-paulo $\mid$ campinas $\mid$ sintese-das-informacoes $-2010>$. Acesso em: 20 jul. 2017. 
paridade ainda maior no acesso à educação superior entre mulher preta e mulher branca; pois a mulher branca está no topo do acesso à educação, seguida do homem branco e preto, depois vem à mulher preta abaixo de todos nessa pirâmide de acesso ${ }^{17}$.

Os reflexos disso é que muitas estão sendo as primeiras da família a acessar o ensino superior e isso se evidencia na fala de Isabela Chioma que veio de uma cidade do interior da Bahia e reporta um pouco de sua realidade, que também é vivida por muitas brasileiras, ao dizer que:

\begin{abstract}
"Eu sou a primeira na minha família, falando de três geraçóes, que eu sou a primeira pessoa que curso o ensino superior. É a gente é de uma cidade do extremo interior da Bahia e que nenhuma de nós tivemos essa possibilidade de inserção no ensino superior. E é muito gratificante e ao mesmo tempo é uma responsabilidade. Mas me dá força em saber que vou ser a primeira eu vou continuar eu vou conseguir eu vou vencer eu vou levar isso para minha cidade, porque quero atuar lá quero voltar para lá". (Depoimento de Isabela Chioma)
\end{abstract}

Cibele da Silva Henriques diz que:

(...) na sociedade Brasileira, o lugar dos homens e mulheres negros nunca foi na escola, mas na lavoura, na casa grande, na senzala, nas ruas ou quando rebelde, na prisão. Assim, o direito dos negros, em especial, das mulheres negras à educação no Brasil foi fruto de lutas travadas pelos Movimentos Negros ${ }^{18}$.

É importante ressaltar que, através das falas das colaboradoras, percebeu-se não apenas a dificuldade de acesso a bens sociais, mas também uma dificuldade de permanência na educação superior, por não ter tido uma educação básica nas escolas públicas que fosse capaz de prepara-las para acessar as universidades públicas ou bolsas de estudos, faz com que reste para elas duas opçóes quais sejam: não seguir os estudos ou ingressar nas universidades privadas o que traz implicaçóes financeiras.

O não ter um ensino básico efetivo causa vulnerabilidades que refletem nelas quando vão acessar a universidade, pois poucas conseguem ingressar nas universidades por questóes financeiras e as que conseguem ingressar sentem dificuldades em acompanhar os cursos e esse apontamento foi feito tanto pelas que acabaram de sair do ensino médio como pelas que pararam os estudos e depois voltaram a estudar. Contudo, essas últimas sentem mais dificuldades ainda que as primeiras. A exemplo disso segue o primeiro trecho da fala de uma colaboradora que concluiu recentemente o ensino médio e ingressou na universidade. O segundo trecho de fala colacionado é de outra colaboradora que conclui o ensino

17 BRASÍLIA. "Dossiê Mulheres Negras: retrato das condiçóes de vida das mulheres negras no Brasil”, organizadoras: Mariana Mazzini Marcondes et al. IPEA. Instituto de pesquisa econômica aplicada. 2013, p 38 .

18 HENRIQUES, C. da S. Do trabalho doméstico à educação superior: a luta das mulheres trabalhadoras negras pelo direito à educação superior. Revista O Social em Questáo - Ano XX - no 37- Jan a abr./2017, p. 153. Disponível em: <http://osocialemquestao.ser.puc-rio.br/media/OSQ_37_art_8_Henriques.pdf >. Acesso em: 10 de nov 11 de 2017. 
médio e só ingressou no ensino superior depois de um tempo.

No dia a dia da universidade quais são suas dificuldades?

“Uhhhhh. É mais de estudo também porque tem coisa que eu não aprendi na escola e tem gente que até já aprendeu porque teve um ensino bom né agora na minha eu não tive nada! E eu estou fazendo engenharia e não tinha matemática no ensino médio nem física nem química ai eu estou aprendendo tudo na raça”. (Depoimento de Keli Badu)

Malu Amina no dia a dia da universidade quais são suas dificuldades?

"Na universidade é um pouco mais difícil assim, porque como tenho vinte nove anos e eu terminei os estudos em 2006 então assim, eu tenho uma dificuldade para acompanhar. Porque a maioria das mulheres que estão lá, saiu do ensino médio e já foi para faculdade e no meu caso não. No meu caso eu tenho que acompanhar o ensino, mas eu fiquei muito tempo parada sem estudar". (grifo nosso) (Depoimento de Malu Amina)

Essa dificuldade decorre de uma estrutura de exclusão que a população preta foi sujeita desde o período imperial, sob o manto da legalidade, e se mantém, até os dias de hoje pela manutenção das desigualdades no acesso à educação básica, pois ainda há uma demarcada diferença entre a escola frequentada pelos brancos e aquela usufruída pelos negros. Essa diferença se evidencia pela carga horária, instalaçóes, material didático, estrutura para que não haja aulas vagas, como é corriqueiro na rede pública, além da qualificação dos professores, entre outros ${ }^{19}$. Essa é uma das formas de opressão que atravessa a população negra. A partir do exposto, Jurema Werneck ao interpretar as múltiplas opressóes a que estão subjugadas as mulheres negras diz:

As mulheres negras são resultado de articulação de heterogeneidades, resultante de demandas históricas, políticas, culturais, de enfrentamento das condiçôes adversas estabelecidas pela dominação ocidental eurocêntrica ao longo dos séculos de escravidáo, expropriação colonial e da modernidade racializada e racista em que vivemos ${ }^{20}$.

\footnotetext{
19 ROSEMBERG, F. Açáo Afirmativa no Ensino Superior Brasileiro: Pontos para Reflexão, 2009, p. 6. Disponível em: <https://www.geledes.org.br/wp-content/uploads/2014/09/AcaoO_AFIRMATIVA_ NO_ENSINO.pdf >. Acesso em: 05/12/2017

20 WERNECK, J. Nossos passos vêm de longe! Movimentos de mulheres negras e estratégias políticas contra o sexismo e o racismo. Revista da ABPN, vol. 1, n. 1, marjun 1992, p. 10.
} 


\section{ESCOLHEM, OU SÁO ESCOLHIDAS?}

A análise das entrevistas viabilizou extrair a categoria de que as mulheres negras não escolhem, mas são escolhidas. Apesar de estarem acessando o ensino superior, estar naquele local não partiu de uma escolha livre delas, mas sim de uma escolha amarrada por condiçôes, sociais, financeiras e culturais que nascem do contexto histórico já tecido acima. Isso ficou nítido na fala abaixo:

\section{Porque você escolheu está universidade UNINOVE? Você consi- derou outras universidades?}

"Escolhi pela nota no Enem também, e por não ter tantas condiçôes para esta fazendo um curso, essas coisas para estar conseguindo uma faculdade pública. É isso". (Depoimento de Keli Dalu)

O estudo realizado por Bianca Santana e Jefferson Mariano em que buscaram compreender a situação da mulher negra na Regiấo Metropolitana de São Paulo e ao final perceberam que, apesar de no Brasil não ter existido leis de segregação racial, como foi o apartheid na África do Sul, os dados "evidenciam que há distritos de pessoas brancas". Em suma, por mais que não exista atualmente uma determinaçáo legal que dite onde negras e negros devem viver, segundo eles "basta olhar os dados para constatar a segregação"21.

A tabela abaixo colacionada, formulada pelos autores supracitados, evidencia essa segregação de espaço no mapa da cidade de São Paulo em que apesar de mulheres negras correspondem a $19 \%$ da população da Capital, a distribuição entre os distritos aponta a enorme assimetria. Os distritos localizados no eixo Sul/sudoeste próximo da regiáo central a população negra é muito reduzida, próximo inclusive do perfil de países europeus. Em contrapartida, os distritos periféricos da capital a situaçáo é diametralmente oposta.

\section{Participaçáo Percentual da Populaçáo Feminina Negra}

\begin{tabular}{|l|l|l|l|}
\hline Distritos da Capital 2010 & Participação & Distritos & Participação \\
\hline Itaim Bibi & 4,56 & Jd. Ângela & 30,37 \\
\hline Vila Mariana & 4,74 & Cidade Tiradentes & 29,01 \\
\hline Alto de Pinheiros & 4,82 & Grajaú & 28,64 \\
\hline Jd. Paulista & 4,92 & Lajeado & 28,45 \\
\hline Perdizes & 5,03 & Parelheiros & 28,17 \\
\hline
\end{tabular}

Fonte: IBGE- Censo Demográfico 2010.

${ }_{21} \quad$ SANTANA, B.; MARIANO, J. Situaçáo da mulher negra na Região Metropolitana de São Paulo: síntese dos indicadores sociais e análises preliminares. p. 6. Disponível em: < http://www.fespsp.org. br/seminarios/anais5/GT12/Situacao_mulher_negra.pdf >. Acesso em: 01 de dez. 2017. 
Os autores afirmam que a segregação é justificada sob argumentos de classe, como: 'custa caro morar no eixo centro-sudoeste', mulheres negras têm menos dinheiro, por isso não vivem nessa região ${ }^{22}$. Com base no que assevera Antônio Sergio Alfredo Guimarães, essa é uma das principais características do racismo brasileiro: "sua invisibilidade, posto que é reiteradamente negado e confundido com formas de discriminação de classe” ${ }^{23}$, uma vez que a segregação de espaço nasce da impossibilidade do negro escolher, pois esse não escolhe viver em determinados distritos, o que acontece é que diante da condição que lhe é colocado, só cabe escolher aquele local, o que contradiz o conceito de escolha.

Seguindo a mesma lógica de raciocínio, pode-se afirmar que há uma segregação racial em relação às universidades, pois existem aquelas que são majoritariamente de brancos e as que são majoritariamente de pretos. Nesse sentido, com base na fala das entrevistadas, a mulher negra não escolhe onde mora, mas onde resta; ela não escolhe no que quer trabalhar, não escolhe onde estudar, mas onde a condição dá e essa condição não é uma condição dela é uma condição posta estruturalmente.

Porque escolheu está universidade, Porque escolheu esse campus?

É eu escolhi essa universidade, sinceramente, foi porque minha nota deu, isso foi o ponto majoritário. Não há essa larga opção de escolha: a minha nota deu, eu entrei. Assim eu não tinha essa grande alternativa. Eu tinha já em mente onde que der eu vou (grifo nosso).

O critério era onde entrava pela nota, qualidade de educação no segundo critério. E por exemplo localidade na hora que me inscrevi eu não levei em consideração a localidade porque só tem um campus da PUC de humanas. No momento da escolha da faculdade eu eliminei algumas e ficou três e as três estavam no centro de São Paulo e as três só tinha uma unidade.

Ah tá!

Eu também pesquisei se após eu terminar a faculdade será que aquela faculdade vai me oferecer oportunidade de continuar o estudo e me disseram que ela dá oportunidade de prosseguir com os estudos. E dentre as três, só uma dava essa oportunidade e as três estavam no centro entáo náo tinha como eu fugir do centro eu tinha que me deslocar e dentre as três só uma tinha essa possibilidade de continuar os estudos.

Entendi eu percebi que você escolheu o período de aula noturno. Você teve possibilidade de escolher outro período? Ou melhor porque esse horário?

\footnotetext{
$22 \quad$ Idem. p. 7.

23 GUIMARÃES, A. S. A. Racismo e antirracismo no Brasil, 2009. p. 226. Disponível em: < https://edisciplinas.usp.br/pluginfile.php/4116181/mod_resource/content/0/A.\%20S.\%20Guimar\%C3\%A3es\%20-\%20Racismo\%20e\%20anti-racismo\%20no\%20Brasil.pdf >. Acesso em: 10 de nov 2017.
} 
Escolhi o noturno porque minha nota deu, no diurno a nota é muito mais alta, é uma quantidade assim de mais de trinta pontos de diferença. Se eu colocasse no diurno eu não seria chamada! (Depoimento de Tainá Dacia)

Apesar de Tainá Dacia ter acessado uma universidade que considerada de boa qualidade ela evidencia que a possibilidade de escolha é restrita a nota obtido por meio da prova de seleção, no caso dela o Enem ${ }^{24}$ que a avaliou e a partir de 'suas condiçôes' será sua margem de escolha. É importante ressaltar que Tainá Dacia foi uma das poucas dentre as entrevistadas, que conseguiu bolsa e pode pensar, como segundo critério, a questáo qualidade. Todas as outras demonstram, em suas falas, que a qualidade não foi levada em consideração, a exemplo disso temos a fala da Isabela Chioma ${ }^{25}$.

Porque escolheu essa universidade?

Essa é uma questão bem complicada. Porque assim, hoje eu me arrependo muito porque a minha universidade eu náo classifico como boa tá! Na minha perspectiva de pensamento! Eu não a classifico ela como boa. Mas infelizmente eu tive que escolher ela por conta que era perto de casa e como eu pensava, que eu na época trabalhava em supermercado de domingo a domingo, eu precisava chegar em casa cedo, porque no outro dia tinha que trabalhar e eu tinha acabado de ser assaltada quando eu fui escolher essa faculdade. Então eu pensava eu tenho que chegar em casa cedo e depois eu ficava pensando, o horário que vou chegar em casa é tarde eu vou ser assaltada de novo! Então eu escolhi uma universidade próxima. Ai eu tive esse privilegio de escolher uma faculdade particular próxima, porque eu me matava trabalhando de domingo para pagar ela né! Então eu pensava isso. Hoje eu penso totalmente diferente, fico pensando porque não tentei uma federal, porque não tentei entrar na lei de cotas, são várias questóes.

Pelo que compreendi você escolheu está universidade/faculdade e esse campo foi por estar próximo de sua casa por conta da mobilidade?

Sim, sim foi. Foi por conta da mobilidade. Porque assim, quando eu comecei a prestar vestibular queria UNINOVE. Porque classificando Anhanguera com UNINOVE, na minha percepção, que não conheço UNINOVE, mas eu entendia que a UNINOVE era melhor e eu queria UNINOVE. Só que para eu chegar em casa da UNINOVE

\footnotetext{
$24 \quad$ Exame Nacional do Ensino Médio.

25 Isabela Chioma veio para São Paulo estudar e também para ajudar financeiramente sua família que se mantém na Bahia.
} 
eu iria chegar mais de meia noite. Eu vi que eu não dava conta. Então fui na primeira que era mais próximo. (Depoimento de Isabela Chioma)

A opção delas é totalmente amarrada em condiçóes que limitam suas escolhas, seja quanto ao período, seja quanto à faculdade. Essas condiçóes amarantes estáo relacionadas a questóes financeiras e de local. A grande maioria das mulheres daquela região tem como critérios iniciais valores das mensalidades, localização e horário. Esses critérios aniquilam a possibilidade de escolher.

Porque escolheu está universidade/faculdade e esse campo? Você considerou outras universidades?

Então a razão de ter escolhido a UNISA foi porque eu avaliei pelo MEC e eu vi que ela tinha uma pontuação boa e que ela é mais próxima da minha casa e o valor é muito acessível; porque nas outras faculdades que eu vi o valor era bem mais alto e fica bem longe da minha casa então eu iria demorar muito mais para poder estar indo do trabalho para a faculdade e de casa para a faculdade.

Tá então era porque era mais próximo?

Sim e mais acessível no valor.

Quais as razóes que te levaram a preferir esse horário?

Porque o período da manhã dá para eu trabalhar para poder pagar a faculdade (risos). (Depoimento de Malu Amina)

\section{DESLOCAMENTO COMO UM DIREITO DE MEIO ESSENCIAL}

Quanto às perguntas voltadas a questóes de deslocamentos e dificuldades enfrentadas para ir e vir das Universidades extraiu-se várias categorias, contudo, o enfoque da discussão se voltará às categorias mais partilhadas pelas colaboradoras quais sejam: segurança, lotação e tempo de espera do ônibus. É importante compreendermos que a construção do Direito a Mobilidade Urbana nasceu do Direito de ir e vir, está intrinsicamente relacionado com o Direito de Liberdade ${ }^{26}$ e pode ser contextualizada a partir do Direito à Cidade e, no caso em estudo trata-se da capacidade de movimento no espaço para a efetivação do Direito à Educação ${ }^{27}$.

$26 \quad$ LIMA, R. M; ALBUQUERQUE. C. de. Direito de ir e vir: Mobilidade Urbana na cidade de Sáo Paulo. 2015, p. 79. IV Congresso Nacional da Federação Nacional Dos Pós-Graduandos em Direito - FEPODI. Acessado em 3/08/17. Disponível no site < https://www.conpedi.org.br/publicacoes/z3071234/ 4moccc71/G7p1Tff24H4e458D.pdf>.

27 BORBA, F. da S. Dicionário de usos do português do Brasil, 2002, p 1049. 
Sob a perspectiva jurídica, mobilidade é Direito Social, inserido no artigo $6^{\circ}$ da CRFB/88 pela emenda Constitucional $n^{\circ} 90 / 2015^{28}$, é instrumento fundamental para a inclusão, mobilidade social das pessoas e instrumento crucial para a realização da cidadania. É por meio dela que os indivíduos podem atender as suas necessidades e desenvolver aptidóes ${ }^{29}$. Conforme Ferreira Filho, a liberdade de locomoção é "o direito de ir e, vir e também ficar (...) é primeira de todas as liberdades, sendo condição de quase todas as demais" 30 .

Com base em estudos realizados em 2012 pela Companha Metropolitano de São Paulo ${ }^{31}$, as mulheres usam mais intensamente o transporte coletivo e se deslocam mais a pé que os homens. Enquanto 34,1\% da mobilidade das mulheres são feitas a pé, o percentual dos homens é de $27,8 \%$. Na mobilidade feita por ônibus, enquanto a mulher atinge o índice de $24,6 \%$, homens ficam em 18,9\%. Mas, quando se trata da mobilidade por automóvel, em que a mulher está dirigindo, o percentual fica em 13,7, enquanto com o homem o valor é $26,4 \%{ }^{32}$. Quando os dados são analisados à luz da renda familiar, "os números mostram um enorme abismo entre mulheres de diferentes classes sociais. Mulheres que ganham até $\mathrm{R} \$ 2.488$, fazem 3\% de suas viagens na direção de veículos. Já mulheres com renda mais alta (em valores que superam $\mathrm{R} \$ 9.330$ ) realizam $45 \%$ de suas locomoçóes" 33 .

$\mathrm{Na}$ análise dos destinos de viagem e motivos, os resultados demostram que $34,9 \%$ das respostas correspondem à educaçáo como motivo de se locomover na cidade para as mulheres, enquanto para os homens o percentual é de $29,1 \%$. Com isso pode se perceber que a educação é majoritariamente buscada por mulheres, mas sua efetivação é majoritariamente concretizada pelo transporte público e a mobilidade a pé $^{34}$.

\footnotetext{
$28 \quad$ A PEC $\mathbf{n}^{\circ} \mathbf{9 0 / 2 0 1 5}$ inseriu transporte entre os direitos sociais e apresentava como justificativa: a importância do transporte, em especial o público, a sua relevância na vida em sociedade como elemento central para concretização de outros direitos, funcionando como vetor de desenvolvimento relacionado à produtividade e à qualidade de vida da população, à mobilidade das pessoas, ao acesso a bens e serviços e à sua função social vital na cidade. Acessado em 19/11/2016. Disponível do site: <http://www.camara.gov.br/ proposicoesWeb/fichadetramitacao?idProposicao $=522343>$.

29 SPECIE, P.; VANETI, V. C.; MOUALLEM, Pedro Salomon Bezerra. A mobilidade das mulheres na cidade de Sáo Paulo. Informe urbanos. no 25 - novembro 2016, Prefeitura de Sáo Paulo. Acessado em 12/06/2017. Disponível no site <http:/www5.each.usp.br/web/prof/oipp/noticias/?32/informe-urbano-amobilidade-das-mulheres-na-cidade-de-sao-paulo>.

30 FERREIRA FILHO, M. G. da S. Curso de direito constitucional. 23.ed. São Paulo: Saraiva 1996 , p. 255.

31 A partir de dados desagregados de padróes de deslocamento na cidade e por meio de pesquisa de origem e destino (OD) que é um levantamento quinquenal, de caráter domiciliar amostral, que descreve as viagens - seus tipos, destinos e modais - realizadas pelos habitantes da Região Metropolitana de São Paulo.

32 MEKARI, D. Estudo traça panorama da mobilidade urbana de mulheres em Sáo Paulo. UOL. Acessado em 12/06/2017. Disponível no site <http://portal.aprendiz.uol.com.br/2016/12/20/estudo-traca-panorama-da-mobilidade-urbana-de-mulheres-em-sao-paulo/>.

33 SPECIE, P.; VANETI, V. C.; MOUALLEM, P. S. B. A mobilidade das mulheres na cidade de Sáo Paulo. Informe urbanos. no 25 - novembro 2016, Prefeitura de Sáo Paulo. Acessado em 12/06/2017. Disponível no site <http://www5.each.usp.br/web/prof/oipp/noticias/?32/informe-urbano-a-mobilidade-das -mulheres-na-cidade-de-sao-paulo $>$.

34 MEKARI, D. Estudo traça panorama da mobilidade urbana de mulheres em Sáo Paulo. UOL. Disponível em: <http://portal.aprendiz.uol.com.br/2016/12/20/estudo-traca-panorama-da-mobilidade-urbana-de-mulheres-em-sao-paulo/>. Acesso em: 12 de jun. 2017.
} 
Os dados expostos acima são corroborados pelo fato de que todas as entrevistadas da presente pesquisa declararam usar o transporte público como meio para acessar e permanecer na faculdade. Apontaram também, como complicadores a seu acesso e permanência na educação superior, a questáo da demora do ônibus em razáo do número reduzido da frota para determinados locais e pontos de ônibus e ruas sem iluminação. Esses fatos aumentam a insegurança na ida e principalmente na volta para casa. Somado a isso, muitas relataram medo e por conta desse medo sobem morros, descem ruas, atravessam vielas, escadóes e avenidas correndo.

Como é para você usar esses meios de transportes que você citou?

Olha é um pouco desconfortável. Porque como moro em um lugar que só tem essa frota de ônibus e de perua, né só tem a Nakamura é desconfortável porque você tem que sempre ficar pegando uma descendo na metade do caminho para poder esperar ela, então é difícil.

Eu não digo que ruim de tudo, pois como moro no final tem a vantagem de pegar ele e ir sentada (risos), mas na volta eu mal consigo entrar na porta (risos) eu me sinto Gisele Bündchen (risos). Porque eu fico tão magrinha que eu não consigo sentar independente de qualquer lugar eu vou o trajeto inteiro em pé. Mas o meu desconforto maior é o tempo de espera e por ele vir lotado quando eu retorno para casa.

Bom você me disse que o tempo gasto do último ponto para sua casa é de cinco minutos me detalha como é esse deslocamento à sua moradia?

Eu sinto muito medo (risos) eu nem olho, eu coloco o celular (risos) no meio do corpo em qualquer parte intima (risos tímida) e vou correndo e não olho para lugar nenhum não olho para ninguém e não olho para lugar nenhum e como diz a minha mãe não olhe para trás que não vai te acontecer nada.

\section{Qual o seu maior medo?}

Ah é o de estupro, porque assalto é o de menos eles levam e possivelmente mata e no estupro eles estupram e talvez matam. Entendeu? Principalmente para mulher! (Depoimento de Malu Amina)

O trecho acima revela um pouco do contexto de violência do bairro que Malu vive. Quanto a lotaçáo ressalta que o desconforto e o tempo de espera da perua no ponto, aumenta o medo, pois quanto mais tarde, mais perigoso fica transitar nos bairros, principalmente para as mulheres, que sofrem com o incomodo de estarem mais expostas a 
violência sexual. Dados da Secretaria de Segurança Pública do Estado de São Paulo ${ }^{35}$ justificam o medo das mulheres em relação a violência sexual, que desde 2015 aponta à crescente no registro desses crimes.

Ocorrências policiais registradas por ano referente aos crimes de estupro. 2019. São Paulo/SP

\begin{tabular}{|l|l|}
\hline Ano & Quantidade de registro de ocorrências \\
\hline $\mathbf{2 0 1 5}$ & 2.087 estupros \\
\hline $\mathbf{2 0 1 6}$ & 2.316 estupros \\
\hline $\mathbf{2 0 1 7}$ & 2.546 estupros \\
\hline $\mathbf{2 0 1 8}$ & 2.590 estupros \\
\hline
\end{tabular}

Fonte: confeccionada pela autora com base em dados da Secretária de Segurança Pública - SSP - 2018. São Paulo ${ }^{36}$.

Em outro depoimento a colaboradora diz:

Certo. Para ver se eu entendi. As suas dificuldades hoje está mais relacionada à segurança?

Sim. É mais a segurança, hoje sim. Porque a faculdade fica bem próximo da minha casa (...). Mas quando eu desço no ponto até minha casa essa é a dificuldade porque é tarde!

\section{Que horas você sai de lá?}

Da faculdade eu saio 22:10, umas 22:30 estou lá (no ponto), mas esse horário é perigoso não tem mais ninguém na rua. Eu chego 22:30 tenho que descer uma rua passar por um córrego, passar por uma biqueira para chegar em casa. (Depoimento de Isabela Chio$\mathrm{ma})$.

Isabela conta que foi vítima de assalto quando escolhia a universidade que iria cursar e ela tinha medo de ser assaltada novamente. A partir dessa fala ela desenha um pouco de como é o bairro à noite e demostra um pouco do risco que ela corre todos os dias ao voltar para casa. Em entrevista com outra colaboradora, moradora do Capão Redondo, a questão da ${ }^{37}$ lotação e da demora do transporte também foi mencionada o que demostra, que na

35 SÃO PAULO. Secretaria de Segurança Pública do Estado de São Paulo. Dados estatísticos do Estado de Sáo Paulo. 2017. Disponível em: < http://www.ssp.sp.gov.br/Estatistica/Mapas.aspx>. Acesso em: 01 de dez. 2019.

$36 \quad$ Idem, 2019.

37 Micro-ônibus que prestam o serviço de transporte público em determinadas regióes. 
região a disponibilidade de ônibus não supre a demanda que a população exige.

\section{Como é para você usar esses meios de transportes?}

Aí é dificultoso, tem vez que eu vou dependurada principalmente na sexta... Sábado de manhã nem tanto, pensado bem também vou dependurada também é complicado. Porque vão muito cheios a aglomeração de pessoas é muita. E esse horário é bem difícil!

\section{Quais as possíveis dificuldades enfrentadas para chegar a univer- sidade e voltar à casa?}

Ah. A espera. As vezes a espera do ônibus é tão longa que você fica bastante tempo no ponto esperando o ônibus porque essa linha é muito demorada. Ah também tem hora que o trânsito é muito grande ali perto do metrô capão redondo. Já teve dias que cheguei em casa meia noite e tanta por causa do trânsito, assim quase uma hora de trânsito para voltar para casa. Então essas são as dificuldades.

\section{Qual essa linha que você falou que demora tanto?}

É a capão redondo ela vem como Capão Redondo e vai como Santo Amaro é a 6048.

\section{(Depoimento de Maria Anaya)}

É importante ressaltar que essa entrevistada mora a $10,3 \mathrm{KM}$ da faculdade que frequenta. Ela não falou na questão da distância, uma vez que escolheu o campus mais próximo de sua casa, apesar disso, no decorrer da entrevista deixou nítido que uma das suas maiores dificuldades é o trânsito lento; o tempo médio para percorrer essa distância com transporte público é no máximo 30 minutos fora do horário de pico, mas é importante ressaltar que na localidade do Capáo que ela mora, não tem corredor de ônibus e o metrô Capáo Redondo é longe de sua casa.

\section{Como você se sente a usar esses meios de transportes?}

Não me sinto muito bem quando pego o ônibus do meu trabalho para a faculdade porque é um horário que tem muita gente, é muito cheio e pega transito né? E é sempre muito lotado, não é confortável. Eu sinto que as mulheres têm que ficar se esquivando, não falo de assédio, mas falo de não se machucar, ter um lugar para segurar. É isso. Não sinto que é um ônibus que comporte todas as nossas necessidades de mulher no espaço que a gente tá. (Depoimento de Isabela Chioma)

O Direito à Mobilidade não pode ser efetivado com um modelo único para toda a cida- 
de; é necessário olhar as particularidades, levando em consideração o gênero, o contexto em que as pessoas estão inseridas, as necessidades e história de cada regiáo. Para tanto, compreender o local é imprescindível para desenvolver políticas públicas em um território periférico. Conforme prevê a Carta Magna em seu artigo 182 caput $^{38}$ e o Plano Diretor Estratégico, no artigo $5^{\circ}$, inciso $\mathrm{V}$, deveríamos ter direito a cidade o que é concretizado através do deslocamento adequado e o Plano Diretor Estratégico da Cidade, no artigo 303, inciso I, tem como objetivo a proteção de grupos sociais tidos como mais vulneráveis, dentre eles reconhece expressamente as mulheres ${ }^{39}$.

\section{CONTINUAR POR QUÊ?}

Como forma de equilíbrio diante de todas as dificuldades apontadas pelas colaboradoras, há alguns mecanismos que as auxiliam na sua resistência diária de permanência e insurgência as dificuldades. Dentre elas os mais apontados são: trabalho, família e sonhos. No trecho abaixo, percebe-se que o trabalho é a forma necessária para permanecerem na universidade.

Tem a questáo financeira que você tem que trabalhar para poder permanecer na faculdade porque minha faculdade é paga. Eu não tenho bolsa eu até tentei, mas eu não consegui ai eu fiquei com medo de deixar passar mais tempo até o dia que eu conseguir uma bolsa... Aí foi quando eu falei nâo vou ir vou arriscar vou ir e vou estudar independente, nem que eu trabalhe em dois três lugares para pagar a faculdade. (Depoimento de Malu Amina)

Dentre as entrevistadas, apenas uma tem bolsa pelo Enem 100\%, as demais pagam suas universidades, não por opção, mas porque é o que restou, pois todas entrevistadas citaram que tentaram bolsa pelo Enem, contudo, apenas uma conseguiu. A questão não é se esforças mais, ou se esforçar menos, mas é uma questão de ter tempo, ajuda e assistência de cursos. Contudo, a maioria das mulheres que moram na periferia vivem outra realidade e por isso usam o tempo prioritariamente pensando em subsistência como trabalho. Além do mais, para a mulher a questão tem um diferencial, porque ainda recai sobre a maioria delas o dever de cuidar da casa e dos afazeres domésticos para depois passarem a pensar nos seus sonhos e nos seus planos.

$38 \quad$ Art. 182. A política de desenvolvimento urbano, executada pelo Poder Público municipal, conforme diretrizes gerais fixadas em lei, tem por objetivo ordenar o pleno desenvolvimento das funçóes sociais da cidade e garantir o bem-estar de seus habitantes. BRASIL. Constituiçáo da República Federativa do Brasil de 1988. DF: Senado Federal, 1988. Acesso em 23/02/2019. Disponível na internet no site: http://www. planalto.gov.br/ccivil_03/constituicao/constituicaocompilado.htm>.

39 SÃO PAULO. Plano diretor Estratégico do Município de Sáo Paulo lei no 16.050 de 2014. Acessado em 12/06/2017. Disponível em: <http://gestaourbana.prefeitura.sp.gov.br/arquivos/PDE_lei_final_aprovada/TEXTO/2014-07-31\%20-\%20LEI\%2016050\%20-20PLANO\%20DIRETOR\%20ESTRAT\%C3\%89GICO.pdf>. 
Bom eu vejo que você é bem corrida... como é mais ou menos sua rotina?

Então é porque minha mãe trabalha né. Ela faz os biquinhos dela né. Então eu chego do meu estágio remunerado já trocando de roupa porque tenho que cuidar do almoço porque meu pai já chega meio dia. Entáo tenho que tentar deixar mais ou menos organizado o quarto para que ele descanse aí nisso eu vou terminando de limpar o resto da casa, aí tem a cozinha isso vai três horas da tarde eu tô lá mexendo. Só depois que termino que vou sentar no computador fazer o trabalho, ler algum texto, fazer um resumo depois eu vou tentar de tarde descansar um pouco, mas nem sempre consigo e no fim de semestre entáo! (Depoimento de Sarah Elon)

Mas, se Deus quiser! Tudo, tudo, tudo vai dar pé Tudo, tudo, tudo vai dar pé (Gilberto Gil - Não Chores mais)

O trecho da musica acima vem ao encontro do contexto dessas mulheres no sentido de que no mundo em que quase tudo dá errado, esperam que, por meio da educaçáo e pela fé, as coisas vão dar pé, por isso continuam. Somado a isso, foi apontado, por quase todas entrevistadas, a educação como um meio de atingir a mobilidade social e também um meio de concretizar sonhos. Alguns trechos de falas demonstram um pouco isso.

\section{O que te faz permanecer na faculdade?}

Ai então eu não vou mentir, eu acho que é um status, porque ninguém da minha família hoje tem uma formação e era um sonho, quando eu estava no ensino médio, houve um tempo que quando a professora falava quem vai fazer faculdade aqui? Eu não levantava a máo, porque eu falava nossa isso nunca vai ser para mim, né eu nunca vou poder ter essa oportunidade por questóes financeiras de mim e da minha família. Depois de um tempo, eu falei, eu quero conseguir eu quero fazer uma faculdade. Depois de mais madura eu escolhi o curso. Então assim é uma realização pessoal. (Grifo nosso)

(Depoimento de Haydee Dandara)

\section{O que promove a sua permanência na universidade?}

Porque quero ter um futuro melhor, por conta do meu filho pelo amor a profissáo que eu quero exercer, quero ser uma boa psicóloga quero poder ajudar as pessoas eu sempre tive isso comigo. Sempre quis ajudar as pessoas. Então é isso ter um futuro melhor, dar um 
futuro melhor para o meu filho e ser boa no que faço. (Grifo nosso)

(Depoimento de Malu Amina)

Porque cursa o ensino superior?

Entáo para ter um futuro melhor, para ter uma vida estável. Porque hoje em dia é difícil conseguir um emprego sem ter o ensino superior.

\section{O que promove a sua permanência na universidade?}

Família! (risos) eu fico pensando na família no futuro em ajudar eles também.

(Depoimento de Keli Badu)

Como visto, a educação é para elas e para toda família meio de ascensão social. A educação se mostra como um agente positivo que viabiliza pensar em uma saída, é uma porta de escape para oferecer mobilidade social. Dyane Brito, fez uma pesquisa sobre o acesso e permanência de negros e negras no ensino superior tendo como estudo de caso a Universidade Federal da Bahia - UFBA. Ao analisar a questão da família a autora diz que

Em muitos casos, esses estudantes negros são os primeiros da família a ingressar na Universidade. Então, a família se reúne para ajudar nos custeios de sua manutenção, sobretudo quando o jovem ingressa em cursos de alto prestígio. A Universidade é, para essas famílias, uma possibilidade concreta de mobilidade social e, consequentemente, a garantia de um futuro melhor ${ }^{40}$.

\section{O que promove a sua permanência na universidade?}

Ah para mim é ter meu objetivo! Impedimento sempre vai existir na nossa vida, então estou fazendo a faculdade porque eu quero futuramente me especializar na área de libras. Então assim, mesmo com

$\overline{40}$ REIS. D. B. Acesso e Permanência de negros (as) no Ensino Superior: O Caso da UFUBA. Org.: Maria Auxiliadora Lopes Maria Lúcia de Santana Braga. $1^{\circ}$ Edição - Brasília: Ministério da Educação, Secretaria de Educação Continuada, Alfabetização e Diversidade: Unesco, 2007, p. 49 a 69. Disponível em: $<$ http://unesdoc.unesco.org/images/0015/001545/154587por.pdf>. Acesso em: $01 \mathrm{de} \mathrm{dez.} 2017$. 
essa dificuldade com trânsito sem trânsito estressada ou não eu estou pensado lá na frente não estou pensando agora porque se eu fosse olhar, talvez eu já teria desistido. Por essa questão que eu continuo caminhando. (Depoimento Sarah Elon)

\section{O que promove a sua permanência na universidade?}

Ah porque eu tenho meus ideais, tenho meus objetivos quero me formar quero ser alguém quero alcançar o meu ideal. O que lutei até aqui eu vou conseguir. Então isso é o que me mantém lá. (sorrisos) (Depoimento de Maria Anaya)

\section{QUESTÓES DE RAÇA}

Das entrevistas também se pode extrair algumas categorias relacionadas à raça, o que não podia ser diferente uma vez que o estudo se volta às questôes de mulheres negras; ou seja, faz-se um estudo interseccionalizado. Durante as conversas, essas mulheres levantaram questóes como o processo de branqueamento, construção da figura do negro na sociedade, a liberdade do negro quanto a sua possibilidade de escolher o lugar que quer ocupar na sociedade e a dor que o racismo causa. É importante ressaltar que todas as participantes disseram que o racismo existe.

\section{Você acredita que temos discriminaçáo racial e de gênero no Bra- sil?}

Ah sim claro que temos. Você vê isso todos os dias, todos os dias. Por exemplo, pelo banco comunitário da tecnologia social fomos finalistas e a gente começou a reparar que não tinha negros ali. Os negros entravam na hora de colocar as coisas para funcionar, para colocar a planta no lugar, para montar o cenário. Mas eu fiquei reparando isso o tempo todo; o tempo todo eu reparo e eu não vejo os negros ocupando esses espaços, então é claro que tem uma questão aí racial. (Depoimento de Haydee Dandara)

Mas o que é discriminação? Conforme o professor Adilson José Moreira, “a palavra discriminação possui uma pluralidade de significados". Discriminar "sugere que alguém foi tratado de forma arbitrária" a partir de categorizaçóes de características das pessoas, "para atribuir a elas consequências" de acordo com essas categorizaçóes ${ }^{41}$. A discriminação aflora de comportamentos de fazer ou do não fazer, pois a estrutura de discriminação instalada

MOREIRA, A. J. O que é discriminação?, 2017, p. 27. 
acaba facilitando a sua reprodução na sociedade e algumas vezes de forma não intencional ou sob o véu da neutralidade, como o náo estabelecer cotas raciais para vagas em concurso público, cotas raciais para vagas no mestrado ou cotas raciais para vagas em cargos da alta administraçáo de uma empresa. Assim, o náo fazer coopera para a reproduçáo dessas mazelas.

$\mathrm{O}$ ato de discriminar viola a expectativa de tratamento isonômico, além de limitar a possibilidade de ação autônoma restringindo o sentido que dá a vida dessas pessoas e suas formas de existência nos espaços da sociedade, uma vez que a discriminação determina o local que se deve estar, que se pode estar e que como deve ser. $\mathrm{O}$ racismo limita o sonhar. Ao procurar entender de que forma essas mulheres acham que o racismo interfere nelas, obteve-se respostas relacionadas diretamente a possibilidade delas e de seus familiares acessarem determinados espaços fora da lógica estabelecida. Segue um trecho de uma das falas:

Olha você vê aqui vários empresários, então você me conta quantos negros e negras têm? Náo tem! Vamos achar os representantes e todos os que estáo envolvidos na instância maior dessa faculdade, por exemplo, e vamos tirar uma foto. Quantos negros você vai achar?

Não quero uma sociedade dessa, tenho um filho negro, marido negro os meus netos vão ser negros eu não quero um mundo desse para eles. E eu vou trabalhar para que eles se coloquem no lugar que eles queiram estar, não o que é o deles, mas o que quer, para ter liberdade de fato, de que o lugar que ele quiser atingir ele vai poder atingir. Sabe? (Depoimento de Haydee Dandara)

Estereótipos e estigmas interferem na possibilidade desse grupo estar em determinados espaços com igualdade. A fala de Haydee se reporta à incerteza do poder de escolha quanto ao que se quer ser, quanto à sua identidade e isso recai não só sobre ela ou sobre sua família; recai em toda a população negra e, nesse caso, as preocupaçóes de uma mãe que sofreu com toda a estrutura de discriminaçáo, que vê o esposo sofrendo com discriminação, pensa como o filho vai enfrentar isso. Cruz e Souza, poeta brasileiro, jornalista engajado nas questóes políticas e literárias de seu tempo, ativista do movimento abolicionista no Brasil $^{42}$, em seu poema feito em 1900, após abolição da escravidão, fala de um sentimento parecido com o que foi retratado pela Haydee Dandara. A sombra disso, percebe-se que os sentimentos que circulavam em 1900, retratados no poema intitulado "Meu Filho", são bem similares aos de hoje. Assim seguem alguns trechos do poema.

Minh 'alma fica presa e se debate ansiosa,

Em vão soluça e clama, eternamente presa

No segredo fatal dessa flor caprichosa,

Do meu filho, a dormir, na paz da Natureza.

42 GELEDÉS. INSTITUTO DA MULHER NEGRA. 111 ANOS SEM CRUZ E SOUZA. 2009. Disponível em: < https://www.geledes.org.br/111-anos-sem-cruz-e-sousa/>. Acesso em: 05 de 122017. 
Minh 'alma se debate e vai gemendo aflita No fundo turbilhão de grandes ânsias mudas:

Que esse tão pobre ser, de ternura infinita,

Mais tarde irá tragar os venenos de Judas!

Por que tantas prisóes, por que tantas cadeias Quando a alma quer voar nos paramos liberta? Ah! Céus! Quem me revela essas Origens cheias

De tanto desespero e tanta luz incerta!

Pois esse filho meu que ali no berço dorme, Ele mesmo táo casto e táo sereno e doce Vem para ser na Vida o vão fantasma enorme Das dilaceraçóes que eu na Minh 'alma trouxe?!

Ah! Vida! Vida! Vida! Incendiada tragédia,

Transfigurado Horror, Sonho transfigurado,

Macabras contorçôes de lúgubre comédia Que um cérebro de louco houvesse imaginado!

Meu filho que eu adoro e cubro de carinhos,

Que do mundo viláo ternamente defendo, Há de mais tarde errar por tremedais e espinhos Sem que o possa acudir no suplicio tremendo.

Vendo-o no berço assim, sinto muda agonia, Um misto de ansiedade, um misto de tortura.

Subo e pairo dos céus na estrelada harmonia E desço e entro do Inferno a furna hórrida, escura.

CRUZ E SOUZA

In Faróis, 1900

Assim, a dor que o racismo causa, desde o período colonial até os dias atuais, reflete nas famílias negras como um todo. Somado a isso, o racismo não é apenas uma prática discriminatória; é um sistema de dominação social porque influencia diferentes aspectos nas vidas de determinados grupos. Ele também determina como os atores nos espaços públicos e privados vão tratar a população negra, "além de reproduzirem o ideário social que legitima a subordinação”. Assim, esses sistemas de subordinação social são responsáveis pela criação de desigualdades de status material e de status cultural e "justifica hierarquias de status entre grupos sociais" provocando desvantagens para alguns que, no caso em estudo, é a população negra em especial a mulher negra, e preservam a compreensão de que os oprimidos são os inferiores, são os errados ${ }^{43}$. O racismo inibe a possibilidade de viver com liberdade, e atravessam essas mulheres e seus familiares determinando os espaços e lugares, mantendo arranjos e diminuindo direitos. Haydee Dandara segue dizendo:

Por isso não dá para você parar, eu faço e trabalho com isso todos

43 MOREIRA, A. J. O que é discriminaçáo? 2017, p. 33. 
os dias ali em casa porque meu marido chega a me dizer que tem lugares que ele não se sente bem, mas é não se sente bem porque ele é negro, ele vê olhares que ele sente isso só ali, então eu trabalho isso dizendo o seu lugar é o lugar que você quiser, se tiver que abrir um barraco, eu abro; eu não quero saber eu quero ter direito, nós temos o direito de estar onde a gente quiser existir. (Depoimento de Haydee Dandara)

\section{CONSIDERAÇÓES FINAIS}

A partir do exposto, percebe-se que o estudo a partir da interseccionalidade da raça, gênero e classe permite perceber formas de opressão singulares dentre elas a conclusão de que mulheres negras que moram na periferia resistem e insiste nos estudos indo contra a lógica imposta a elas historicamente.

A mobilidade é instrumento e meio fundamental para efetivação de Diretos. Contudo, quando ela não é pensada a partir do cenário que as pessoas vivem, pode funcionar como verdadeiro obstáculo. No presente estudo percebeu-se que há um constante medo de quase todas as entrevistadas em relação à segurança principalmente quando voltam a noite da faculdade. Muitas apontaram o medo de assalto, outras apontaram o medo constante de estupro.

Percebeu-se também que quase todas participantes apesar de estarem cursando o ensino superior demonstram em suas falas que não escolheram, mas sim foram escolhidas, uma vez que só podem ter acesso a educação dentro daquelas condições que foram colocadas, assim não há uma real escolha quanto as universidade, pois antes de chegar a escolha da universidade precisam ver preços mais acessíveis, localidade mais próxima do bairro e mesmo as que ingressam por meio de bolsa deixam em evidencia que entraram porque a nota deu, ou seja, não escolhi fui escolhida a partir da avaliação que é imposta a elas.

O racismo e um sistema de dominaçáo social que influencia diferentes aspectos da vida de determinados grupos. Ele determina como os atores nos espaços públicos e privados Assim, esse sistema de subordinação social é responsável pela criação de desigualdades de status material e de status cultural. Apareceram como meios de resistência mecanismos de bolsas e auxílios como passe livre, família, amor a profissão, o querer atingir seus objetivos, sonhos e também o trabalho.

Assim conclui-se que: a mobilidade precisa ser pensada para a mulher no bairro e a partir do olhar feminino. É necessário o resgate da importância da mobilidade urbano-periférico, e de se desenhar soluções a partir da participação popular, em especial das mulheres da respectiva regiáo, como forma de equacionar as dificuldades impostas à mobilidade em regiôes periféricas. Esse é um dos caminhos possíveis, que podem diminuir os impactos negativos na vida delas e fomentar sua permanência no ensino superior, o que é imprescindível para o desenvolvimento político cidadão e social em um Estado democrático de direito. 


\section{REFERÊNCIAS}

BORBA, F. da S. Dicionário de usos do português do Brasil. São Paulo: Ática, 2002.

BRASIL, Decreto $n^{\circ} 7.247$, de 19 de abril de 1879. Reforma o ensino primario e secundario no municipio da Côrte e o superior em todo o Imperio. Disponível no site: <http://www2.camara.leg.br/legin/fed/decret/1824-1899/decreto-7247-19-abril1879-547933-publicacaooriginal-62862-pe.html>. Acesso em: 08 jun. 2017.

BRASIL. Decreto n 21.076 de 24 de fevereiro 1932. Código Eleitoral. Disponível no site: <http://www2.camara.leg.br/legin/fed/decret/1930-1939/decreto-21076-24-fevereiro-1932-507583-publicacaooriginal-1-pe.html>. Acesso em: 23 out. 2017.

BRASIL. Constituiçáo da República Federativa do Brasil de 1988. DF: Senado Federal, 1988. Disponível na internet no site: http://www.planalto.gov.br/ccivil_03/constituicao/constituicaocompilado.htm. Acesso em 23 jun. 2017.

BRASIL. Proposta de emenda à Constituiçáo da República Federativa do Brasil $\mathbf{n}^{\circ}$ 90/2011. Disponível na internet no site: <http://www.camara.gov.br/proposicoesWeb/ fichadetramitacao?idProposicao=522343 >. Acesso em: 03 ago. 2015.

BRASIL. Plano diretor Estratégico do Município de Sáo Paulo lei no 16.050 de 2014. Disponível no site <http://gestaourbana.prefeitura.sp.gov.br/arquivos/PDE_lei_final_ aprovada/TEXTO/2014-07-31\%20-\%20LEI\%2016050\%20-20PLANO\%20DIRETOR\%20ESTRAT\%C3\%89GICO.pdf>. Acesso em: 12 jun.2017

BRASÍLIA. "Dossiê Mulheres Negras: retrato das condiçóes de vida das mulheres negras no Brasil", organizadoras: Mariana Mazzini Marcondes et al. IPEA. Instituto de pesquisa econômica aplicada. 2013, p 168. Disponível no site < file://C:/Users/Renata\%20Miranda/Downloads/dossie_mulheres_negrasipea.pdf>. Acesso em: 20 jul. 2017

FERREIRA FILHO, M. G. da S. Curso de direito constitucional. 23.ed. São Paulo: Saraiva 1996.

GIL, A. C. Métodos e Técnicas de Pesquisa Social, $2^{\circ}$ Ed. Editora Atlas S.A - 1989, p. 206.

GUIMARÃES, A. S. A. Racismo e antirracismo no Brasil. São Paulo: Editora 34, 2009. Disponível no site: < https://edisciplinas.usp.br/pluginfile.php/4116181/mod_resource/ content/0/A.\%20S.\%20Guimar\%C3\%A3es\%20-\%20Racismo\%20e\%20anti-racismo\%20no\%20Brasil.pdf >. Acesso em: 10 nov. 2017.

GELEDÉS. INSTITUTO DA MULHER NEGRA. 111 ANOS SEM CRUZ E SOUZA. 2009. Disponível no site: < https://www.geledes.org.br/111-anos-sem-cruz-e-sousa/>. Acesso em: 05 dez. 2017.

HENRIQUES, C. da S. Do trabalho doméstico à educaçáo superior: a luta das mulheres trabalhadoras negras pelo direito à educaçáo superior. Revista $\mathrm{O}$ Social em 
Questão - Ano XX - no 37- Jan a abr./2017, p. 153 a 171. Disponível no site: < http:// osocialemquestao.ser.puc-rio.br/media/OSQ_37_art_8_Henriques.pdf >. Acesso em: 10 nov. 2017.

MEKARI, D. Estudo traça panorama da mobilidade urbana de mulheres em Sáo Paulo. UOL. Disponível no site <http://portal.aprendiz.uol.com.br/2016/12/20/estudotraca-panorama-da-mobilidade-urbana-de-mulheres-em-sao-paulo/>. Acesso em: 12 jun. 2017.

MENDES, C. E. Os sentidos de futuro para jovens: por caminhos do capáo redondo e do jardim Ângela na periferia paulista. Disponível no site <file://C:/Users/Renata\%20Miranda/Downloads/mendes_corrigida-1.pdf>. Acesso em: 23 jun. 2017.

MOREIRA, A. J. O que é discriminação? - Belo Horizonte (MG): Letramento: Casa do Direito: Justificando, 2017, p. 198.

REIS. D. B. Acesso e Permanência de negros (as) no Ensino Superior: O Caso da UFUBA. Org.: Maria Auxiliadora Lopes Maria Lúcia de Santana Braga. ${ }^{\circ}$ Edição - Brasília: Ministério da Educação, Secretaria de Educação Continuada, Alfabetização e Diversidade: Unesco, 2007, p. 49 a 69. Disponível em: <http://unesdoc.unesco.org/images/0015/001545/154587por.pdf>. Acesso em: 01 dez. 2017.

ROSEMBERG, F. Açáo Afirmativa no Ensino Superior Brasileiro: Pontos para Reflexáo, 2009, p. 25. Disponível no site: < https://www.geledes.org.br/wp-content/ uploads/2014/09/AcaoO_AFIRMATIVA_NO_ENSINO.pdf >. Acesso em: 05 dez. 2017

SÃO PAULO. Regulamento de 22 de agosto de 1887 da província do Estado de São Paulo. Regulamento para instrucçáo publica Provincial 1887. Disponível no site: < http:// www.usp.br/niephe/bancos/legis_detalhe.asp?blg_id=205>. Acesso em: 23 nov.2017.

SÃO PAULO. Instituto Brasileiro de Geografia e Estatística, censo demográfico. Sistema nacional de informação de gênero. Total de pessoas pretas ou pardas entre 18 e 24 anos de idade que frequentam o ensino superior. Disponível no site $<$ http://cidades.ibge. gov.br/cartograma/mapa.php?lang $=\&$ coduf $=35 \&$ codmun $=350950 \&$ idtema $=132 \&$ cod $\mathrm{v}=\mathrm{v} 43$ \&search=sao-paulo|campinas|sintese-das-informacoes-2010>. Acesso em 20 jul. 2017.

SÃO PAUlO, PREFEITURA. BolitimCEInfo Censo Demográfico, 2010, n 02, p. 9. Disponível no site <http://www.prefeitura.sp.gov.br/cidade/secretarias/upload/saude/ arquivos/publicacoes/Boletim_CEInfo_Censo_02.pdf> Acesso em: 25 jul. 2017

SANTANA, Bianca; MARIANO, Jefferson. Situação da mulher negra na Região Metropolitana de Sáo Paulo: síntese dos indicadores sociais e análises preliminares. Disponível no site: < http://www.fespsp.org.br/seminarios/anais5/GT12/Situacao_mulher_negra.pdf >. Acesso em: 01 dez. 2017.

SÃO PAULO. Secretaria de Segurança Pública do Estado de São Paulo. Dados estatís- 
ticos do Estado de Sáo Paulo. 2017. Disponível no site: < http://www.ssp.sp.gov.br/ Estatistica/Mapas.aspx>. Acesso em: 01 dez. 2017

SÃO PAULO. Secretaria de coordenaçáo das subprefeituras. Diagnóstico de M’boi Mirim, 2008, p.74. Disponível em: < http://ww2.prefeitura.sp.gov.br/arquivos/subprefeituras/spmb/dados/diagnosticos_de_mboi_mirim-08_08_08.pdf >. Acesso em: 23 jul. 2017.

SPECIE, P.; VANETI, V. C.; MOUALLEM, P. S. B. A mobilidade das mulheres na cidade de São Paulo. Informe urbanos. no 25 - novembro 2016, Prefeitura de São Paulo. Disponível em: <http://www5.each.usp.br/web/prof/oipp/noticias/?32/informe-urbano -a-mobilidade-das-mulheres-na-cidade-de-sao-paulo>. Acesso em: 12 jun. 2017.

SPINK; BRIGAGÁO; NASCIMENTO; CORDEIRO. A produçáo de informaçáo na pesquisa social: compartilhando ferramentas. Rio de Janeiro: Centro Edelstein. 2014. p 334.

SPINK, P. K. O pesquisador conversador no cotidiano. Revista de Psicologia Social. v.20. Porto Alegre, 2008. Disponível em: <http://www.scielo.br/scielo.php?script=sci_arttext\&pid=S0102-71822008000400010>. Acesso em: 23 jun. 2017.

VITUNO, J. A Amostragem em Bola de Neve na Pesquisa Qualitativa: Um Debate em Aberto. Revista dos pós-graduandos em ciências sociais. IFCH Unicamp. Temáticas, Campinas, 22, (44): 203-220, ago./dez. 2014. Disponível no site: < https://www.ifch. unicamp.br/ojs/index.php/tematicas/article/view/2144/1637>. Acesso em: 07 jul. 2017.

WERNECK, J. Nossos passos vêm de longe! Movimentos de mulheres negras e estratégias políticas contra o sexismo e o racismo. Revista da ABPN, vol. 1, n. 1, marjun 2010. 